\title{
Foreign Direct Investment and Productivity Growth in Eastern European Countries*
}

Özcan Karahan ${ }^{1}$, Olcay Çolak ${ }^{2}$

${ }^{1}$ Bandırma Onyedi Eylül University, Department of Economics

${ }^{2}$ Uşak University, Department of Economics

\begin{tabular}{l}
\hline ARTICLE INFO \\
\hline Article History \\
Received 4 August 2021; \\
Accepted 5 December 2021 \\
\hline JEL Classifications \\
F21, F23, D24, O52
\end{tabular}

ABSTRACT

\section{Purpose:}

Our study aims to investigate the technological spillover effects of Foreign Direct Investment flows to Eastern European Countries. This study has guided by new growth theories arguing that Foreign Direct Investment has a significant potential for improving the productivity growth rate of host countries through technology transfer.

Design/methodology/approach:

The impact of potential spillover effects associated with FDI flows on productivity growth has been examined by constructing the baseline specification of which Gersl et al. (2007) and Stancik (2009) based on Cobb-Douglas type production function. Through the baseline model, we performing conventional linear panel data models namely the fixed effect and random effect. For the robustness of the empirical findings, we also employ a dynamic panel data estimator in the framework of the GMM technique.

Findings:

Results based on the fixed effect estimator show that there are no horizontal and forward spillovers while positive backward spillovers prevail in both manufacturing and services sectors, that is also confirmed by the findings of the dynamic panel data (GMM) estimator. Research limitations/implications:

Our findings regarding the presence of positive backward spillovers versus the absence of horizontal and forward spillovers are consistent with the results of most empirical studies dealing with Eastern European Countries. However, our study has also revealed that these results do not differ between the manufacturing and service sectors in Eastern European Countries.

Keywords:

Foreign Direct Investment Productivity Growth,

Eastern European Country

\section{Originality/value:}

In the literature focusing on Eastern European Countries, many studies investigate the presence of the spillover effect by not making a distinction between the manufacturing and services sectors. Our study is one of the first to examine how spillovers from FDI affect domestic firms in two different sectors namely manufacturing and services. Thus, this study contributes to related literature by showing whether the spillovers from FDI exist differently in the manufacturing and services sector or not.

\section{Introduction}

After the new growth theories proposed by Romer (1986, 1990), Lucas (1988) and Grosman and Helpman (1991) the importance of technology as an endogenous determinant of growth has been emphasized, and gaining access to new technology has become a very important factor for the sustainable growth. Thus, a new challenge has arisen for developing countries to achieve high growth rates and reach the level of developed countries. Because developing countries have a very low capacity to produce new technology due to some structural problems. In order to overcome this challenge, international technology transfer has become the biggest agenda item for developing countries. This agenda has also been valid for the transition economies in Eastern European Countries (EECs) to catch up with the developed economies in the European Union. In this context, economists have recommended Foreign Direct Investment (FDI) made by Multinational Companies (MNCs) as the most important channel for international technology transfer.

Foreign direct investment has become a driving force of growth for the developing economy by bringing not only new capital but also new technology and know-how. Thus, FDI inflows make a significant contribution to the

${ }^{\dagger}$ Corresponding Author: Özcan Karahan

Email: $\underline{\text { okarahan@bandirma.edu.tr }}$ 
production level of the host country in direct and indirect ways. FDI inflows directly contribute to the level of income growth and indirectly affect productivity in the host country. The direct benefit from FDI inflows to host country production capacity arises from its positive impact on the level of domestic capital stock. In this way, FDI inflow increases the production level of the local economy by expanding the investment stock of the host country. Besides this direct effect, FDI inflow indirectly affects the host country's production level through new technology transfer. The fact of transferring knowledge and technology parallel with FDI inflows is a feature that makes FDI much more useful for the host country's economy. Thus, the foreign firm's presence affects the production process of the host country positively and contributes to an increase in the domestic productivity of the economy.

The indirect advantages provided by FDI on the host country's production level via technology transfer are called the spillover effect. In the case of the spillover effect, multinational companies (MNCs) make a significant contribution to the efficiency of the production process of local companies through new technology transfer. During the spillover effect from FDI, domestic firms can easily reach advanced production knowledge and better managerial expertise. That means the presence of foreign companies affects the productivity of domestic companies in the economy. In general terms, the spillovers from FDI are defined as benefits for indigenous firms through the enlargement of their efficiency in the production process. Thus, local firms gain impressive efficiency in their production processes and consequently, they become the engine of economic growth based on productivity.

Spillovers from FDI generate efficiency gains to domestic firms in both the same industry and different industries. Efficiency gains from incoming FDI to domestic firms in the same industry are regarded as horizontal spillovers. The existence of foreign companies also increases the efficiency of domestic firms in different industries, which is called vertical spillovers. Vertical spillovers operate via two channels of transmission mechanism as backward spillovers and forward spillovers. Vertical technology transfers taking place from FDI to domestic suppliers and buyers are called backward spillovers and forward spillovers, respectively. Thus, the presence of vertical spillovers from FDI can take place through both backward and forward linkages in cross-industries.

Technology diffusion channels of FDI as indicated above have increased their importance and attracting FDI has become a popular way for technology transfer policy. Eastern European Countries (CECs) struggling with a large technological deficiency have also shown a considerable effort for technology transfer via FDI inflows. Therefore, these countries have created special incentives in order to attract FDI in the last decades. Thus, an important experience has emerged to empirically analyse the spill over effect of FDI in EECs. Accordingly, this study tries to determine the spillover effect of FDI on productivity growth using the yearly panel data set over the period of 20082014 in 10 Eastern European Countries including Bulgaria, Czech Republic, Estonia, Hungary, Latvia, Lithuania, Poland, Romania, Slovakia, and Slovenia. Our study is one of the first to examine how FDI presence affects domestic firms in two different sectors namely manufacturing and services. While analysing the impact of FDI on domestic firm productivity in EECs, we deal with the spillovers from FDI in the manufacturing and services sectors separately.

The rest of the paper is organized as follows. Section 2 reviews the empirical literature focusing on FDI spillovers. Section 3 explains the data and methodology. Section 4 shows the empirical results. The final section concludes and makes some policy implications.

\section{Review of Literature}

Foreign Direct Investment can contribute to the economic growth in the host country through technology spreads (spillovers) called indirect impact. In this section, we review the studies examining the contribution of FDI to economic growth through enhancing the efficiency of production capacity. In addition, we consider the researchers that try to determine the contributions offered by FDI inflows to the productivity of local firms in the Eastern European area. Thus, we review the studies that examine the spillovers from FDI in Eastern European Countries using firm-level data in the framework of micro-analyses. In the framework of related literature indicated above, most of the studies have focused on whether the existence of spillovers from FDI or not. It seems that most of them have not found positive spillovers from FDI in Eastern European Countries. These studies refer to the inadequacies in the absorption capacity of the local companies related to not receiving the expected positive contributions from the FDI. In other words, empirical results mostly show that the degree to which domestic firms may benefit from spillovers from FDI depends on the absorptive capacity of domestic firms (Konings, 2001; Tytell and Yudaeva, 2006; Nicolini and Resmini, 2006; Gersl et al. 2007, Damijan et al. 2013; Estrin and Uvalic, 2016; Karahan 2016).

On the other hand, when the related literature is reviewed, it is also seen that some studies have made more detailed analyses to determine which type of spillovers effect has occurred rather than the presence of the spillover effect. Spillovers from FDI operate via two channels of transmission mechanism as horizontal spillovers and vertical spillovers. Horizontal spillovers from FDI occur through contacts between foreign subsidiaries and their local competitor in the same sectors. Vertical spillovers from FDI taking place through contacts between foreign affiliates and local firms in upstream (supplier) and downstream (customer) sectors, which are referred to as backward spillovers and downward spillovers, respectively. Looking at the studies trying to determine the form of spillovers, it seems that technological diffusion from FDI operates in the form of vertical spillovers rather than horizontal spillovers much more. As can be seen below, many studies related to Eastern European countries using firm-level data at country and multi-country levels have confirmed the existence of powerful vertical spillover effects from FDI (Schoors and Tol, 2002; Javorcik, 2004; Marcin, 2008; Ayyagari and Kosova, 2010; Jude, 2012).

Concerning country-level studies in Eastern European Countries, Schoors and Tol (2002) analyse the influences of FDI on labour productivity of domestic firms in Hungary. Empirical results indicate the presence of forward linkage spillovers. Besides, foreign firms have a positive spillover effect on labour productivity of local firms within sectors, 
which confirms the positive horizontal spillover effects. However, the forward linkage spillovers are much more important compared to positive horizontal spillover effects. Empirical findings also indicated that absorption and openness play a significant role in the process of spillovers from FDI. Javorcik (2004) focuses on the inter-industry and intra-industry spillovers from FDI based on firm-level data between 1993 and 2000 from Lithuania. The results of the study failed to find positive intra-industry spillovers from FDI.

On the other hand, the results are consistent with the presence of productivity spillovers taking place through backward linkages. This suggests that productivity spillovers arise from the contacts between foreign affiliates and their domestic suppliers. However, no evidence of forward spillovers is found which means there are no spillovers stemming from multinational presence in sectors buying intermediate inputs. Marcin (2008) examines horizontal and vertical spillovers by exploiting firm-level panel data spanning the data between 1996 and 2003 related to the Polish corporate sector. Main findings indicated that local firms benefit from a foreign presence in the same industry and in downstream industries. The absorptive capacity of domestic firms is highly relevant to the size of spillovers. Therefore, there are reasons to support policies strengthening the absorptive capacity of domestic firms. Policymakers should focus on not only attracting foreign investors but also enhancing the absorptive capacity of domestic companies. Stancik (2009) analysis the spill over effects from FDI by focusing on the sales growth rate of domestic firms in the Czech Republic. Using firm-level data from 1995-2005, the empirical study indicates the negative backward spillover effects since the sales growth rates of domestic firms mostly decrease in the presence of foreign companies downstream. Regarding horizontal spillover effects, they are statistically weaker and much smaller in magnitude. Positive backward spillovers are present, which indicates that domestic firm in the upstream sector increases their sales. The overall impact of FDI on the sales of Czech domestic companies is mostly negative. That means Czech domestic companies are not profiting from the presence of foreign investors.

Ayyagari and Kosova (2010) analyse the spillover effects from FDI focusing on the domestic firm entry in the Czech Republic during 1994-2000. They find evidence of vertical entry spillovers in the form of both backward and downward spillovers in the industries. FDI in downstream industries initiates entry in upstream sectors, as well as FDI in upstream industries, initiates entry in downstream sectors. The findings also indicate the existence of positive horizontal spillovers from FDI in the industries. A larger foreign presence in the industry stimulates the entry of domestic firms within the same industry. Besides, benefits from FDI entry spillovers via horizontal channels are mainly driven by FDI from members of the EU. However, empirical results show that the volume of vertical spillover effects is higher than horizontal spillovers in the industries. Jude (2012) empirically estimates the magnitude of technological spillovers from FDI using a firm-level dataset of the Romanian economy for the period 1999-2007. He used time-varying Input-Output tables in order to compute spillover effects. Econometric results show that local suppliers benefit from positive backward spillovers, which confirm the productivity gains in upstream sectors. However, local clients are negatively affected by forward spillovers, which indicate the losses in downstream sectors. Thus, from a policymaker's point of view, policies aiming to encourage the entry of new foreign firms to downstream sectors in order to minimize the negative forward spillovers. Fatima (2016) analyses the productivity spillovers from foreign direct investment (FDI) using Turkish firm-level data for the period 2003-2010. Thus, the empirical model focused to determine the technology transfer capacity of the Turkish economy based on FDI-induced spillovers via the channels of horizontal and vertical linkages. The empirical results show that the presence of FDI decreases the productivity of local competitors, which indicates negative horizontal spillovers. On the other hand, vertical linkages exert a positive impact on the local productivity levels, which confirms the positive backward and forward spillovers. Positive vertical spillovers call policies for strengthening of supplier-buyer relationship between local and multinationals. Ciani and Imbruno (2017) examine the spillover effects of FDI in Bulgaria focusing on the export performance of Bulgarian manufacturing firms. Using firm-level data for the period 2004-2006, they find positive forward spillover on export performance. Conversely, empirical results show negative backward and horizontal spillover on export performance of Bulgarian manufacturing firms. Foreign presence hurts both local competitors and suppliers in upstream sectors. Therefore, empirical findings suggest that policymakers in Bulgaria design policies oriented to attract FDI in downstream sectors to generate much more positive effects from FDI in the economy.

Looking at the multi-country level studies in Eastern European Countries, it seems that many studies investigate the presence of the spillover effect rather than how it occurs. In addition, when investigating the spillover effect in multi-country studies, it is seen that there is no distinction between the manufacturing sector and the manufacturing sector. The results obtained generally show that the spillover effects from FDI were either not at all or were realized in a weak way. Konings (2001) investigate empirically the effects of FDI on the productivity of domestic firms in Bulgaria, Romania, and Poland by using firm-level panel data. Estimation results of the fixed effects model using instrumental variables in the general methods of moment technique show no evidence of positive horizontal spillovers to domestic firms but negative horizontal spillovers to domestic firms in Bulgaria and Romania. Thus, empirical results suggest a negative competition effect dominates positive technology effects in Bulgaria and Romania. This means that, although productivity in the economy increases in the long run, inefficient firms will lose their market share in the short run due to foreign competition. Tytell and Yudaeva (2006) examine the spillovers from FDI by using firm-level data for manufacturing firms in four countries of Eastern Europe including Russia, Ukraine, Poland, and Romania. They found that not all FDI has automatically positive spillover effects on domestic firms. Spillovers exit positively only in the cases of export-oriented FDI. Empirical results also demonstrated that benefits from FDI are likely to materialize once a relatively large stock of foreign capital is accumulated. Besides, spillovers occur predominantly in the more educated and the less corrupt regions that show the significance of the absorptive capacity of domestic firms in reaping the benefits of FDI. Nicolini and Resmini (2006) examined the productivity effects 
generated by FDI on domestic firms in Bulgaria, Romania, and Poland. Panel data from firm level in three transition countries are analysed by using random-effects models. Empirical findings indicated that only more productive domestic firms could reap the benefits from FDI. Thus, it is clearly indicated the importance of the absorptive capacity as a determinant of productivity spillovers. Besides, findings also show that the level of the technological level of foreign firms also affects the degree of benefits from spillovers for local firms. Spillovers emanating from high-tech foreign are so much high compared to those generated by low-tech foreign firms.

Gersl et al (2007) focus on the analysis of productivity spillovers from FDI in CEE countries. Using firm-level data on manufacturing industries for the period 2000-2005, they examine the link between the productivity of the local firms and foreign presence in the same sector and in sectors linked via the production chain. Empirical results do not show significant horizontal and vertical spillovers in all countries. Moreover, the degree of spillover effect varies depending on other conditions and characteristics on the industry and national level. Damijan et al (2013) analyse the spillovers through FDI on a unique firm-level dataset of ten Eastern European Countries- Bulgaria, the Czech Republic, Croatia, Estonia, Latvia, Lithuania, Poland, Romania, Slovenia, and Ukraine. Empirical results show that local firm heterogeneity is essential in the occurrence of positive spillover effects of FDI in the host country. The heterogeneity of firms in terms of absorptive capacity, size and technology levels affect the benefits from FDI. Thus, findings indicated that spillovers through FDI on a set of ten transition countries do not exist automatically. Firm heterogeneity acts a significant role when determining the spillovers from FDI on domestic firm performance. Estrin and Uvalic (2016) explored the impact of foreign direct investment on the economies of the Western Balkans covering Albania, Bosnia and Herzegovina, Croatia, Macedonia, and Serbia. In order to determine the horizontal spillovers regression analysis has been performed on data from the manufacturing sector for the period 2002-2012. Empirical findings indicated that FDI has had no horizontal effects on key measures of performance of the manufacturing industry in Western Balkan countries. Thus, they concluded that the main constraints arising from institutional and economic factors possibly limited the potential benefits of FDI in Western Balkan.

\section{Data and Methodology}

In this section, we empirically analyse spillovers from FDI on domestic companies in Eastern European countries, both within industries (horizontal) and across industries (vertical). Accordingly, after given the knowledge about the data set and methodology, econometric results will be explained.

\subsection{Data Set}

In order to analyze the potential spillover effects of foreign direct investments (FDI) on productivity, we utilize annual data over the period of 2008-2018 in 10 Eastern European Countries including Bulgaria, Czech Republic, Estonia, Hungary, Latvia, Lithuania, Poland, Romania, Slovakia, Slovenia. Annual industry-level data for manufacturing and services sectors classified according to NACE Revision 2 codes have been sourced from Eurostat.

Table 1 displays the list of variables and a brief explanation including data sources.

Table 1: List of Variables

\begin{tabular}{|l|l|l|}
\hline \multicolumn{1}{|c|}{ Variables } & \multicolumn{1}{|c|}{ Description } & \multicolumn{1}{c|}{ Source } \\
\hline 1.Gross value added (lnY) & $\begin{array}{l}\text { Natural log of gross value added } \\
\text { (million Euro), 2008-2018 }\end{array}$ & $\begin{array}{l}\text { EUROSTAT } \\
\text { National Accounts }\end{array}$ \\
\hline 2.Capital input (lnK) & $\begin{array}{l}\text { Natural log of total fixed assets } \\
\text { (million Euro), 2008-2018 }\end{array}$ & $\begin{array}{l}\text { EUROSTAT } \\
\text { National Accounts }\end{array}$ \\
\hline 3.Labor input (lnL) & $\begin{array}{l}\text { Natural log of total employment } \\
\text { (thousand), 2008-2018 }\end{array}$ & $\begin{array}{l}\text { EUROSTAT } \\
\text { National Accounts }\end{array}$ \\
\hline $\begin{array}{l}\text { 4.Horizontal spillovers } \\
\text { (lnhorzm, lnhorzs)* }\end{array}$ & $\begin{array}{l}\text { Natural log of share of foreign enterprises } \\
\text { in industries, 2008-2018 }\end{array}$ & $\begin{array}{l}\text { EUROSTAT } \\
\text { Structural Business Statistics }\end{array}$ \\
\hline $\begin{array}{l}\text { 5.Backward spillovers } \\
\text { (lnbackm, lnbacks)** }\end{array}$ & $\begin{array}{l}\text { Natural log of weighted share of output } \\
\text { supplied to other sectors, 2008-2018 }\end{array}$ & $\begin{array}{l}\text { EUROSTAT, ESA } \\
\text { Supply, Use, Input Output Table }\end{array}$ \\
\hline $\begin{array}{l}\text { 6.Forward spillovers } \\
\text { (lnforwm, lnforws)*** }\end{array}$ & $\begin{array}{l}\text { Natural log of weighted share of output } \\
\text { supplied by other sectors, 2008-2018 }\end{array}$ & $\begin{array}{l}\text { EUROSTAT, ESA } \\
\text { Supply, Use, Input Output Table }\end{array}$ \\
\hline
\end{tabular}

Note: * lnhorzm, and lnhorzs show the horizontal spillovers in manufacturing and services sectors respectively.

** lnbackm and lnbacks show the backward spillovers in manufacturing and services sectors respectively.

**** lnforwm and lnforws show the forward spillovers in manufacturing and services sectors respectively.

In order to capture potential horizontal spillover effects of FDI, we need statistics regarding the total number of foreign enterprises. For this purpose, we compiled the data on the total number of enterprises including the foreign enterprises (inward foreign affiliate) from the Structural Business Statistics (SBS) of Eurostat. A foreign affiliate is defined as an enterprise resident in a country that is under the control of an institutional unit not resident in the same country, and control is defined as foreign affiliates' chain of control. FDI reflects this control and lasting interest 
implying that a long-term relationship exists between the investor and enterprise. Such an interest is formally deemed to exist when a direct investor owns $10 \%$ or more of the voting power on the board of directors or equivalent.

Vertical spillovers that arise from inward FDI have been identified by utilizing the industry-level data from Eurostat's ESA Supply, Use, and Input-Output Table on an annual basis which is calculated by ESA 2010 Methodology. Supply and use tables are helpful tools to show the production process for a particular product and industry that are classified by NACE Revision 2 codes. We use to supply data at basic prices for each country on the industry level to determine the foreign share of output within and across sectors to identify backward and forward linkages associated with foreign capital.

In the Cobb-Douglas production-function frame, to analyse the effect of inward FDI on total factor productivity, we also use proxies for capital and labour used as input in the production process. In this context, as a proxy for physical capital input, we use gross fixed capital formation for each sector covering the fixed assets of the firm in terms of current prices in Euro and deflated by GDP deflator. For labour input, we get total employment in each sector and both variables collected in the National Accounts database of Eurostat.

\subsection{Model Specification}

The impact of potential spillover effects associated with FDI flows on productivity growth has been examined by constructing the baseline specification of which Gersl et al. (2007) and Stancik (2009) introduced by assuming the following conventional Cobb-Douglas type production function:

$$
\mathrm{Y}_{\mathrm{ijt}}=\mathrm{A}_{\mathrm{jt}} \mathrm{f}\left(\mathrm{K}_{\mathrm{ijt}}, \mathrm{L}_{\mathrm{ijt}}\right)
$$

where $\mathrm{Y}_{\mathrm{ijt}}$ is the value added, $\mathrm{A}_{\mathrm{jt}}$ is the technology parameter associated with the FDI, $\mathrm{K}_{\mathrm{ijt}}$ and $\mathrm{L}_{\mathrm{ijt}}$ is the physical capital and labor input in corresponding sector $\mathrm{j}$ at time t. By totally differentiating both sides of Equation 1 , the following expression is yield.

$$
\Delta \mathrm{Y}_{\mathrm{ijt}}=\Delta \mathrm{A}_{\mathrm{jt}} / \mathrm{A}_{\mathrm{jt}}+\beta_{1} \Delta \mathrm{K}_{\mathrm{ijt}}+\beta_{2} \Delta \mathrm{L}_{\mathrm{ijt}}
$$

$\Delta \mathrm{A}_{\mathrm{jt}} / \mathrm{A}_{\mathrm{jt}}$ is the productivity growth rate associated with the horizontal and vertical spillovers caused by inward FDI while $\beta_{1}$ and $\beta_{2}$ are the respective elasticity parameters of capital and labor inputs. Productivity growth rate is affected by FDI and components of potential spillovers caused by FDI are horizontal, backward and forward linkages expressed by the following equation form.

$$
\Delta \mathrm{Ajt} / \mathrm{Ajt}=\beta_{\mathrm{o}}+\beta_{3} \text { horz }_{\mathrm{jt}}+\beta_{4} \text { back }_{\mathrm{jt}}+\beta_{5} \text { forw }_{\mathrm{jt}}+\varepsilon_{\mathrm{jt}}
$$

In Equation 3, horz $\mathrm{j}_{\mathrm{jt}}$, back $\mathrm{j}_{\mathrm{jt}}$ and forw $\mathrm{jt}_{\mathrm{jt}}$ represent horizontal, backward and forward spillovers while $\varepsilon_{\mathrm{jt}}$ shows disturbance term that represents the potential effects of productivity shocks within or across industries. Analogues to the approach that is developed by Gersl et al. (2007), we identify the variable for horizontal spillovers that is associated with the presence of foreign enterprises via diffusion of technology in sector $\mathrm{j}$ at time in the following form:

$$
\text { horz }_{\mathrm{jt}}=\sum_{\mathrm{i}=1}^{\mathrm{n}} \mathrm{FF}_{\mathrm{jt}} / \sum_{\mathrm{i}=1}^{\mathrm{k}} \mathrm{AF}_{\mathrm{jt}}
$$

where $\mathrm{FF}_{\mathrm{jt}}$ represents the number of foreign enterprises while $\mathrm{AF}_{\mathrm{jt}}$ represents the total number firms in sector $\mathrm{j}$ at time $\mathrm{t}$.

Secondly, domestic companies within the sector rather than that foreign enterprise may have direct contact with that foreign enterprise as they provide or supply necessary inputs for the production. Hypothetically, foreign enterprises are regarded as technologically efficient companies and require efficient use of inputs may enforce domestic companies to produce inefficient manner, and indigenizing the new technologies within the production process is considered as vertical spillovers of FDI (Javorcik 2004; Stancik 2009). In this context, vertical spillovers are considered as backward and forward linkages of FDI and represented by the weighted share of output supplied by all sectors to sector $\mathrm{j}$ at time $\mathrm{t}$ and weighted share of output supplied by sector $\mathrm{j}$ to all sectors at time $\mathrm{t}$ respectively and constructed in the following forms:

$$
\begin{aligned}
\text { back }_{k j t} & =\sum_{k: k \neq j} \alpha_{j k t} \text { horz }_{j t} \\
\text { forw }_{j k t} & =\sum_{k: k \neq j} \alpha_{k j t} \text { horz }_{j t}
\end{aligned}
$$

where $\alpha_{\mathrm{jkt}}$ is the share of output supplied by sector $\mathrm{j}$ to other sectors while $\alpha_{\mathrm{kjt}}$ represents the share of output supplied by all sectors to sector $\mathrm{j}$ at time $\mathrm{t}$.

Having considered these facts, we estimate the following log-linear production in Cobb-Douglas sense at industrylevel in the following form:

$$
\ln Y_{i j t}=\beta_{0}+\beta_{1} \operatorname{lnK}_{i j t}+\beta_{2} \operatorname{lnL}_{i j t}+\beta_{3} \operatorname{lnhorz}_{\mathrm{ijt}}+\beta_{4} \operatorname{lnback}_{\mathrm{ijt}}+\beta_{5} \operatorname{lnforw}_{\mathrm{ijt}}+\sigma_{\mathrm{ij}}+\varphi_{\mathrm{jt}}+\varepsilon_{\mathrm{ijt}}
$$

where dependent variable $\ln \mathrm{Y}_{\mathrm{ijt}}$ is the natural logarithm of gross value added whereas $\ln \mathrm{K}_{\mathrm{ijt}}$ and $\operatorname{lnL}_{\mathrm{ijt}}$ represent the natural logarithms of gross fixed capital formation and total employment respectively. Spillover variables are represented by $\operatorname{lnhorz}_{\mathrm{ijt}}, \operatorname{lnback}_{\mathrm{ijt}}$, lnforw $_{\mathrm{ijt}}$ namely horizontal spillovers, backward spillovers and forward spillovers in each sector (j). In addition, $\sigma_{\mathrm{ij}}$ and $\varphi_{\mathrm{jt}}$ denote the country-specific and time-specific effects whereas $\varepsilon_{\mathrm{ijt}}$ denotes the conventional error term. To this end, we will conduct the standard panel data models, namely the fixed effect (FE) and random effect (RE) estimators. Regarding the conformity of random effect estimator over fixed effect estimator, the Hausman test is also performed.

To make comparisons and test the robustness of the findings, Equation 6 will be considered in a dynamic panel fashion and estimated by using the Generalized Methods of Moments (GMM) technique that is pioneered by Arellano and Bond (1991). Estimation of Equation 7 by the standard panel data models might subject to have some drawbacks. The main drawback is connected with Equation 6 stems from the emergence of technological spillovers with lags. On 
the other hand, estimation of Equation 7 by standard panel data models might cause endogeneity bias and produce inconsistent estimates. As Konings (2001) states that, this would be the case if productivity shocks may have an effect on the input factors employed by the firms in the industry. The other reason is productivity shocks may have an effect on spillovers that would lead to the endogeneity of the spillovers. Thus, in order to circumvent the endogeneity issue, the GMM estimator introduces the instrumental variables. Another advantage of the GMM estimator is the inclusion of the lagged dependent variable ( $\ln \mathrm{Y}_{\mathrm{ijt}}$ in our case) as an independent variable. Hence, the dynamic characteristics of the specification emerge by the introduction of the one-period lagged dependent variable that is not estimated by the standard panel data estimators efficiently. In this context, Equation 7 is rewritten to be estimated by the GMM estimator by the inclusion of the one-period lag of the dependent variable in the following form:

$$
\ln Y_{i j t}=\beta_{0}+\beta_{1} \ln Y_{i j t-1}+\beta_{2} \operatorname{lnK}_{\mathrm{ijt}}+\beta_{3} \operatorname{lnL}_{\mathrm{ijt}}+\beta_{4} \operatorname{lnhorz}_{\mathrm{ijt}}+\beta_{5} \operatorname{lnback}_{\mathrm{ijt}}+\beta_{6} \operatorname{lnforw}_{\mathrm{ijt}}+\varepsilon_{\mathrm{ijt}}
$$

where $\ln \mathrm{Y}_{\mathrm{ijt}-1}$ is the one period lag of the dependent variable. The remainder of the variables in Equation 8 is the same with Equation 7 as outlined above. Both equations will be estimated by each sector to reveal whether the spillover effects are valid or not for 10 selected Eastern European Countries.

\section{Estimation Results}

Through the baseline model specification, which is driven in Equation 7, we embark upon our empirical treatment regarding the investigation of spillover effects by performing conventional linear panel data models namely the fixed effect $(\mathrm{FE})$ and random effect (RE). Table 2 reports the results of estimating baseline specification in Equation 7 . It seems that the signs and significance of the coefficients are consistent with each other regardless of the estimation methods namely the fixed effect $(\mathrm{FE})$ and random effect $(\mathrm{RE})$. However, the results of the Hausman Test indicate that estimations that are carried out by random effect (RE) estimator are not appropriate. Hence, the fixed effect (FE) estimator should be considered since it produces results that are more reliable.

According to the findings of fixed effect (FE), there are no horizontal spillovers caused by inward FDI in the manufacturing and services sectors since the coefficients for horizontal spillovers are statistically insignificant. Similarly, the coefficients of forward spillovers are insignificant in the manufacturing and services sectors. Thus, results do not report any significant relationship between foreign presence and productivity growth of downstream industries in each sector. However, the results highlight the presence of backward spillovers in the manufacturing and services sectors. In other words, the results strikingly indicate that positive backward spillovers prevail in manufacturing and services sectors by the inward FDI flows. The coefficient of backward spillovers in the manufacturing sector indicates that a $1 \%$ increase in foreign presence within upstream sectors yields a $0.164 \%$ productivity increase for domestic firms while it accounts for $0.135 \%$ of productivity increases in the services sector.

On the other hand, factor productivity is captured by the introduction of the capital and labor input which are represented by the natural logarithms of gross fixed capital formation (lnKit) and total employment (lnLit) in each sector. Both coefficients are positive and statistically significant to the extent that the rise in both inputs reveals the productivity gains in each sector. However, the coefficients of labor input are relatively larger than capital input in not only services but also the manufacturing sector. The possible reason for the relatively dominant effect of labor input on production might stem from the presence of labor-intensive technologies in the production process of Eastern European Countries. Within the presence of relatively scarce capital input makes labor more productive by the increments to the overall capital stock of these countries.

Table 2: Standard Panel Data Estimation Results

\begin{tabular}{|c|c|c|c|c|}
\hline \multirow[t]{2}{*}{ Dependent Variable: $\ln Y_{\text {it }}$} & \multicolumn{2}{|c|}{ Manufacturing } & \multicolumn{2}{|c|}{ Services } \\
\hline & $\mathrm{FE}$ & $\mathrm{RE}$ & $\mathrm{FE}$ & $\mathrm{RE}$ \\
\hline Constant & $1.831(1.000)^{* * * *}$ & $2.885(0.426)^{*}$ & $-1.398(2.600)$ & $3.275(0.718)^{*}$ \\
\hline $\operatorname{lnK}$ & $0.357(0.048)^{*}$ & $0.384(0.045)^{*}$ & $0.094(0.040)^{* *}$ & $0.186(0.053)^{*}$ \\
\hline $\ln \mathrm{L}$ & $0.867(0.187)^{*}$ & $0.639(0.089)^{*}$ & $0.613(0.0876)^{*}$ & $0.824(0.098)^{*}$ \\
\hline lnhorzm & $-0.001(0.009)$ & $-0.007(0.010)$ & & \\
\hline lnbackm & $0.164(0.063)^{* *}$ & $0.127(0.043)^{* *}$ & & \\
\hline lnforwm & $0.005(0.007)$ & $0.003(0.007)$ & & \\
\hline lnhorzs & & & $-0.004(0.004)$ & $-0.002(0.002)$ \\
\hline lnbacks & & & $0.135(0.053)^{* *}$ & $0.072(0.013)^{*}$ \\
\hline lnforws & & & $0.094(0.104)$ & $0.052(0.044)$ \\
\hline \multicolumn{5}{|l|}{ Model Diagnostics } \\
\hline \# of obs. & 110 & 110 & 110 & 110 \\
\hline Wald statistics & & $349.63[0.000]^{*}$ & & $130.33[0.000]^{*}$ \\
\hline F-statistics & $33.88[0.000]^{*}$ & & $10.70[0.000]^{*}$ & \\
\hline Hausman test & & $27.91[0.000]^{*}$ & & $10.43[0.033]^{* *}$ \\
\hline R-squared & 0.92 & 0.93 & 0.88 & 0.92 \\
\hline
\end{tabular}

Notes: *, ** and *** denote the significance levels at $1 \%, 5 \%$ and $10 \%$ respectively. Robust standard errors are shown in parenthesis whereas p-values of diagnostics are shown in brackets. 
For the robustness of the empirical findings reported by the fixed effect (FE) method and possible methodological drawbacks as outlined in the previous section, we employ a dynamic panel data estimator in the framework of the GMM technique and the relevant results are reported in Table 3.

The results of the GMM estimator are in line with the fixed effect (FE) method that is reported in Table 2. There are no horizontal spillovers in both sectors associated with the presence of foreign firms since the coefficients of horizontal spillovers are statistically insignificant. The results also indicate that there are no forward linkages in both sectors as the coefficients of forward spillovers are statistically insignificant. Thus, domestic firms in downstream industries of each sector do not benefit from the increased efficiency of the foreign owned companies. On the other hand, we obtain positive backward linkages for both sectors, as the coefficients of backward spillover effects are positive and statistically significant. In this case, domestic firms experience productivity gains by supplying inputs to foreign firms. Findings show that $1 \%$ increase in foreign presence accounts for the increase in productivity by 0.091 and 0.047 in the manufacturing and services sectors, respectively.

In addition, the results show that the signs of capital (lnKit) and labor (lnLit) inputs are positive and statistically significant through the expectations. The coefficients of labor input are relatively larger than capital input, which indicates the presence of labor-intensive technologies in the production process of Eastern European Countries.

Finally, the below segment of Table 3 reports the diagnostics regarding the GMM estimation methods. Arellano and Bond autocorrelation test results show that there is no second-order autocorrelation within the residuals of the first order-lagged dependent variable. Sargan test examines the over-identification of the instruments and results reveal that the null hypothesis regarding the over-identification of instruments is rejected.

Table 3: GMM Estimation Results

\begin{tabular}{|c|c|c|}
\hline Dependent Variable: ln Y & Manufacturing & Services \\
\hline $\begin{array}{l}\text { Constant } \\
\ln \mathrm{Y}_{\mathrm{t}-1} \\
\operatorname{lnK} \\
\operatorname{lnL} \\
\operatorname{lnhorzm} \\
\text { lnbackm } \\
\text { lnforwm } \\
\text { lnhorzs } \\
\text { lnbacks } \\
\text { lnforws }\end{array}$ & $\begin{array}{c}-0.877(1.061) \\
0.700(0.113)^{*} \\
0.044(0.041)^{* * *} \\
0.078(0.011)^{*} \\
0.009(0.009) \\
0.091(0.030)^{*} \\
0.043(0.046)\end{array}$ & $\begin{array}{l}2.027(0.805)^{* * *} \\
0.875(0.043)^{*} \\
0.010(0.005)^{* * *} \\
0.017(0.005)^{*}\end{array}$ \\
\hline \multicolumn{3}{|l|}{ Model Diagnostics } \\
\hline $\begin{array}{l}\text { \# of obs. } \\
\text { Wald } \mathrm{X}^{2} \\
\text { Arellano-Bond test for } \operatorname{AR}(2) \\
\text { Sargan test }\left(\mathrm{x}^{2}\right)\end{array}$ & $\begin{array}{c}90 \\
1058.80[0.000] \\
-1.59[0.110] \\
47.55[0.223]\end{array}$ & $\begin{array}{c}90 \\
4468.98[0.000] \\
-1.46[0.144] \\
28.47[0.869]\end{array}$ \\
\hline
\end{tabular}

Notes: *** and *** denote the significance levels at $1 \%, 5 \%$ and $10 \%$ respectively. Robust standard errors are shown in parenthesis whereas p-values of diagnostics are shown in brackets.

Overall, our findings regarding the presence of positive backward spillovers versus the absence of horizontal and forward spillovers are consistent with the results of most empirical studies dealing with Eastern European Countries. The absence of horizontal spillovers attests to the findings revealed by Konings (2001), Tytell and Yudaeva (2006), Nicolini and Resmini (2006), Damijan et al. (2013), and Estrin and Uvalic (2016). On the other hand, the presence of positive backward spillovers is indicated by most of the empirical studies that deal with Eastern European countries (Schoors and Tol, 2002; Javorcik, 2004; Stancik, 2009; Aygari and Kosova, 2010; Fatima, 2016; Gersl et al. 2007). However, our study is one of the first to examine how spillovers from FDI affect domestic firms in two different sectors namely manufacturing and services. Thus, this study contributes to related literature by indicating that the form of spillovers from FDI do not differ between the manufacturing and service sectors in Eastern European Countries.

\section{Conclusion}

FDI inflows have an important potential for technology transfer and therefore productivity increase in the production process of host countries. For this reason, Eastern European countries have made great efforts to attract foreign capital to their countries in the past period and have made significant progress in this way. Therefore, a lot of research has been performed in the literature on Eastern European Countries in order to determine the role of FDI in technology transfer. However, when the relevant literature is reviewed, it is seen that the focus is on whether there are spreads related to FDI spillovers. However, studies focusing on what kind of diffusion occurs through which channels are still quite limited. Moreover, in most of the existing studies, it is seen that there is no distinction between manufacturing and service sectors while investigating the effect of technological diffusion provided by the presence of foreign investments. Unlike many other studies in the literature, we examined the operating channels of the spillover effect of foreign investments in Eastern European countries in manufacturing and service sectors separately. 
In order to analyse the channels of spillover effects from FDI in manufacturing and service sectors, annual data over the period of 2008-2018 in 10 Eastern European Countries have been used. Panel Data Estimation Results based on the fixed effect (FE) estimator show that there are no horizontal and forward spillovers caused by inward FDI in manufacturing and services sectors. The coefficients for horizontal and forward spillovers are statistically insignificant. Nevertheless, the results indicate that positive backward spillovers prevail in both sectors by the inward FDI flows. For the robustness of the empirical findings reported by the fixed effect (FE) method, we employed dynamic panel data (GMM) estimator. The results of the GMM estimator confirm the findings of the fixed effect (FE) method that there are no horizontal and forward spillovers in both sectors. Dynamic panel data estimator also indicates the existence of positive backward spillovers for both sectors since the coefficients of backward spillover effects are positive and statistically significant. Empirical findings also indicate that the contribution of labor input to the production process is relatively larger than capital input, which attests to the presence of labor-intensive technologies in Eastern European Countries.

Our findings regarding the presence of positive backward spillovers versus the absence of horizontal and downstream spreads are consistent with the results of most empirical studies dealing with Eastern European Countries. However, unlike other studies, the existence of backward spreads was separately determined for both manufacturing and service sectors. Thus, our study has revealed that the backward spillovers, which are widely proven in the literature focusing on Eastern European Countries, do not differ between the manufacturing and service sectors. Accordingly, this study contributes to understanding whether the presence of spillover effects differs between manufacturing and service sectors. However, more comprehensive studies are needed to determine which factors other than sectoral differences affect spillover. In this context, the research can be expanded by seeking answers to questions such as whether the spillovers are affected by the distance between the host and the home country and the technological sophistication of the affiliate. On the other hand, our study results attesting only backward spillovers enhance the general view that the technology spillover effect of foreign investment in Eastern European Countries is not strong. Therefore, the findings show that in addition to attracting foreign investments to the country, a comprehensive policy design process is needed for the realization of the technology transfer expected from foreign investments. There is a greater need to design policies to increase the absorption capacity of domestic firms in both sectors of Eastern European Countries. In this context, given that both manufacturing and services sectors are labour-intensive, it seems that policies to improve human capital are much more effective in enhancing firms' absorption capacity. Besides, policy makers may be advised to strengthen the network between local suppliers and foreign buyers. Policies to encourage research and development investments by local firms can also be implemented. In addition, in order to reduce the negative horizontal spillover, regulations can be made against the exclusion effect of foreign firms on local firms.

\section{References}

Arellano M \& Bond S (1991). Some Tests of Specification for Panel Data: Monte Carlo Evidence and an Application to Employment Equations. Review of Economic Studies, 58 (2), 277-297.

Ayyagari, M. \& Kosova, R. (2010). Does FDI Facilitate Domestic Entry? Evidence from the Czech Republic. Review of International Economics, 18 (1), 14-29.

Ciani, A. \& Imbruno, M. (2017). Microeconomic Mechanisms Behind Export Spillovers from FDI: Evidence from Bulgaria. Review of World Ecoomics, 153, 703-734.

Damijan, J. P., Rojec, M., Majcen, B., \& Knell, M. (2013). Impact of Firm Heterogeneity on Direct and Spillover Effects of FDI: Micro-Evidence from Ten Transition Countries. Journal of Comparative Economics, No: 41, 895-922.

Estrin, S. \& Uvalic, M. (2016). Foreign Direct Investment in the Western Balkans: What Role Has It Played During Transition. Comparative Economic Studies, 58, 455-483.

Fatima, S. T. (2016). Productivity Spillovers from Foreign Direct Investment: Evidence from Turkish Micro-Level Data. The Journal of International Tared \& Economic Development, 25 (3), 291-324.

Gersl, A., Rubene, I. \& Zumer, T. (2007). Foreign Direct Investment and Productivity Spillovers: Updated Evidence from Central and Eastern Europe. Czech National Bank Working Paper Series, No: 8.

Grossman, G. M. \& Helpman, E. (1991). Quality Ladders in the Theory of Growth. 4. Review of Economic Studies, 58, 43-61.

Javorcik, B. S. (2004). Does Foreign Direct Investment Increase the Productivity of Domestic Firms? In Search of Spillovers Through Bacward Linkages. The American Review, 94 (3), 605-627.

Jude, C. (2012). Horizontal and Vertical Technology Spillovers from FDI in Aastern Europe. Halshs - 00828022.

Karahan, Ö. (2016). "Technology Spillover from Foreign Direct Investment in Turkey," International Journal of Business and Economic Sciences Applied Research (IJBESAR), 9(3), 7-12.

Konings, J. (2001). The Effects of Foreign Direct Investment on Domestic Frms: Evidence from Firm-Level Panel Data in Emerging Economies.Economics of Transition, 9 (3), 619-633.

Lucas, R. E. (1988). On the Mechanics of Economic Development. Journal of Monetary Ecrnomics, 22, 3-42.

Marcin, K. (2008). How Does FDI Inflow Affect Productivity of Domestic Firms? The Role of Horizontal and Vertical Spillovers, Absorptive Capacity and Competition. The Journal of International Trade $\mathcal{E}^{2}$ Economic Development. 17 (1), 155-173.

Nicolini, M. \& Resmini, L. (2006). The Impact of MNEs on Domestic Firms in CEECs: A Micro-Econometric Approach, Mimeo, ISLA, Bocconi University, Milan.

Romer, P. (1986). Increasing returns and Long Run Growth. Journal of Political Economy, 94, 1002-1037.

Romer, P. (1990). Endogenous Technical Change. Journal of Political Economy, 98, 71-1102.

Schoors, K. \& Tol, B. (2002). Foreign Direct Investment Spillovers within and between Sectors: Evidence from Hungarian Data. 
Ghent University Working Paper, No: 2002/157.

Stancik, J. (2009). FDI Spillovers in the Czech Republic: Takeovers vs. Greenfields. European Union Economic and Financial Affairs Economic Papers, No: 369.

Tytell, I. \& Yudaeva, K. (2006). The Role of FDI in eastern Europe and New Independent States: New Channels for the Spillover Effect. Centro Studi Luca D'Agliano Development Studies Working Papers, No: 217.

This is an Open Access article distributed under the terms of the Creative Commons Attribution Licence

(c) (1) 